\title{
The Last Journey of Peter Tessem and Paul Knutsen, 1919
}

\author{
WILLIAM BARR'
}

\begin{abstract}
In September 1919, when Amundsen's ship Maud left her winter quarters near Mys Chelyuskina to continue east along the Siberian coast, two men, Peter Tessem and Paul Knutsen, were deliberately left behind. Their instructions were to wait until freeze-up, then sledge to the weather station at Dikson in order to deliver the expedition's mail and the accumulated scientific data of the past year. The two men did not reach their destination. In the spring of 1921 a Soviet-Norwegian search expedition, travelling overland, established that the two men had passed Mys Vil'da in November 1919; at that point all was well. Farther west, near Poluostrov Mikhaylova, the remains of a campfire were found together with charred bones which were thought to be the remains of one of the Norwegians; it was assumed that one man had died and that his companion had cremated the corpse. In 1922 a geological expedition led by N. N. Urvantsev found the mail and scientific data that Tessem and Knutsen had been carrying, abandoned near the mouth of the Zeledeyeva, and the Norwegians' skis, abandoned at the mouth of the Uboynaya. Finally a skeleton, thought to be that of Tessem, was found on the shore within sight of the weather station at Dikson. Recent evidence indicates that the campfire near Poluostrov Mikhaylova relates to the missing Rusanov expedition, and not to Tessem and Knutsen; furthermore, there has been recent debate as to whether the skeleton so close to Dikson was that of Tessem or Knutsen.
\end{abstract}

Key words: Maud expedition, Kara Sea littoral, searches for Tessem and Knutsen 1921-1922

RÉSUMÉ. En septembre 1919, lorsque Maud, le navire d'Amundsen, quitta son site d'hivernage près de Mys Chelyuskina afin de continuer son voyage vers l'est le long de la côte sibérienne, deux hommes, Peter Tessem et Paul Knutsen, furent délibérément laissés au site. Ils devaient y rester jusqu'au gel et ensuite se rendre en traîneau à la station météorologique à Dikson afin d'y livrer la poste de l'expédition et les données scientifiques accumulées durant l'année précédente. Les deux hommes n'arrivèrent jamais à leur destination. Au printemps de 1921, une expédition de recherches soviétique-norvégienne, voyageant par voie terrestre, établit que les deux hommes étaient passés par Mys Vil'da en novembre 1919 et qu'à ce pointlà, tout allait bien. Plus à l'ouest, près de Poluostrov Mikhaylova, les restes d'une feu de camp furent trouvés, ainsi que des os carbonisés que l'on pensait être ceux d'un des Norvégiens; il fut supposé que l'un des hommes mourut et que son compagnon incinéra le corps. En 1922, une expédition géologique dirigée par N.N. Urvantsev trouva le courrier et les données scientifiques qu'avaient portés Tessem et Knutsen, abandonnés près de l'embouchure de la Zeledeyeva, ainsi que les skis des Norvégiens, abandonnés à l'embouchure de l'Uboynaya. Un squelette, supposément celui de Tessem, fut enfin trouvé sur la côte en vue de la station météorologique de Dikson. Des trouvailles récentes signalent que le feu de camp prés de Poluostrov Mikhaylova se rapportait à l'expédition disparue de Rusanov, plutôt qu'à Tessem et Knutsen. De plus, des discussions récentes soulèvent des questions selon lesquelles le squelette trouvé si près de Dikson serait celui de Tessem ou de Knutsen.

Mots clés: expédition du Maud, littoral de la mer Kara, recherches 1921-1922 pour Tessem et Knutsen

Traduit pour le journal par Maurice Guibord.

\section{INTRODUCTION}

On 18 July 1918 Roald Amundsen's ice-strengthened ship Maud put to sea from Vardo in northern Norway, bound through the Northern Sea Route to the vicinity of Ostrov Vrangelya (Amundsen, 1921; H. Sverdrup, 1933). Amundsen's intention was to repeat the drift of Nansen's Fram across the Arctic Basin, carrying out a more sophisticated scientific program. He also hoped that by starting the ice drift farther east than Nansen's starting point, he could attain higher latitudes than Fram had.

The ship's total complement numbered only nine men: Roald Amundsen, expedition leader; Halmer Hansen, Maud's captain; O. Wisting, mate; Dr. Harald Sverdrup, chief scientist; K. Sundbeck, chief engineer; G. Olonkin, second engineer; M. Rønne, sailmaker, Paul Knutsen, able-bodied seaman; Peter Tessem, carpenter, and E. Tønnesen, ablebodied seaman.

Heavy ice in Yugorskiy Shar delayed Maud's entry into the Kara Sea until 17 August, and slowed by further heavy ice thereafter, she did not reach Dikson until 31 August. Continuing east on 4 September she managed to round Mys Chelyuskina, but on 13 September was brought to a halt by ice about $33 \mathrm{~km}$ farther east in a bay which Amundsen named Maudhavet (now Bukhta Mod) (Amundsen, 1921; H. Sverdrup, 1933). New ice formed rapidly and soon Maud was firmly frozen in; her crew settled down to a wintering considerably farther west than they had anticipated (Fig. 1). An extensive program of scientific observations was mounted and in the spring sledge trips were made around the northern part of Poluostrov Taymyr and also to Ostrov Alekseya (now Ostrov Malyy Taymyr).

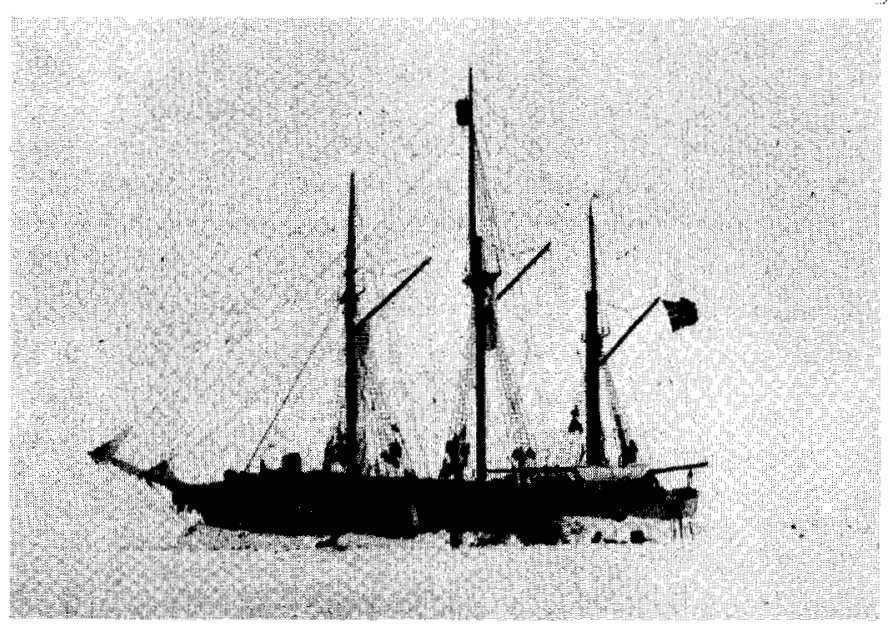

FIG. I. Maud in winter quarters, Bukhta Mod, near Mys Chelyuskina, 1918-19.

As the summer advanced, however, Amundsen began to give some thought to ensuring that his accumulated scientific data reach civilization. According to plan Maud would enter 
the ice in the vicinity of Ostrov Vrangelya in the late summer of 1919, and it could be anticipated that her drift across the Arctic Basin might last a further two or three years. Hence Amundsen was anxious that news of the expedition's progress and its scientific findings thus far be sent south as soon as possible, and decided to dispatch a sledge party to Dikson with mail and the scientific data.

The choice of personnel for this task appears to have been a fairly obvious one. Peter Tessem (Fig. 2) had been suffering from chronic headaches throughout the winter (Amundsen, 1927; Wisting, 1930; H. Sverdrup, 1933) and was not enthusiastic about staying aboard Maud for a prolonged drift. Amundsen then asked for volunteers to accompany Tessem; everyone, with the exception of Sverdrup, who felt his place as chief scientist was clearly on board, volunteered. Amundsen's choice was Paul Knutsen (Fig. 2), largely because Knutsen had wintered with Otto Sverdrup aboard Eclipse in the Kara Sea in 1914-1915 and knew the locations of caches of provisions left by Sverdrup on that occasion (Sverdrup, 1928; Starokadomskiy, 1976). The most important of these was at Mys Vil'da, where Eclipse had wintered.
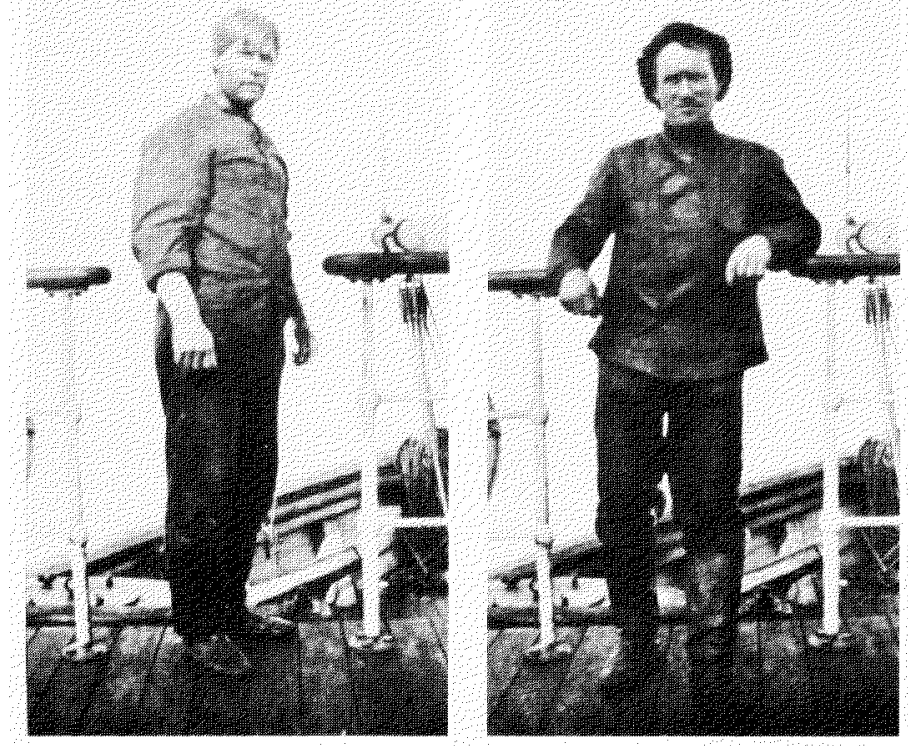

FIG. 2. Paul Knutsen (left) and Peter Tessem on board Maud.

Both men appeared to be extremely well suited for the task they were to undertake. Both had considerable experience of living and travelling in the Arctic. As already mentioned Knutsen had wintered previously on the coast which they were to travel, and Tessem had been to Zemlya Frantsa Iosifa as carpenter with the Ziegler Polar Expedition of 1903-1905 (Fiala, 1907). Indeed, Tessem had volunteered to be one of the relatively small party that stayed at Camp Abruzzi at Bukhta Teplitsa on Ostrov Rudol'fa when the bulk of the party retreated south to Mys Flora, and thus had twice wintered at almost $82^{\circ} \mathrm{N}$. More recently, during May 1919 Knutsen had accompanied Harald Sverdrup on a sledge trip from Bukhta Mod south to Zaliv Simsa and back via the interior, while Tessem had led the expedition to Ostrov Alekseya (Ostrov
Malyy Taymyr) during the spring (Amundsen, 1921).

Nevertheless, the journey with which they were faced (Fig. 3) was quite a formidable one. Without taking into account detours caused by pressure ice, open leads, snow-free areas, and rocky terrain, the distance from Mys Chelyuskina to Dikson following the general trend of the coast is approximately $1000 \mathrm{~km}$. Even so, Amundsen commented that: "The journey these two men proposed for themselves was, in their eyes and ours, mere child's play for experienced Northmen like themselves. This was a journey of 500 miles $(800 \mathrm{~km})$ across the snow to Dickson [sic] Island - very much less of an undertaking, for example, than my trip from Herschel Island to Fort Egbert"' (Amundsen, 1927:92). The reference is to Amundsen's winter sledge trip with the mails from Herschel Island, where Gjoa wintered in 1905-06, to Eagle City on the Yukon River, accompanied by Captain Mogg and two Inuit (Amundsen, 1908). The distance involved is about $700 \mathrm{~km}$, not taking into account the inevitable sinuosities of the route. The party left Herschel Island on 24 October 1905 and reached Eagle City at the beginning of December, i.e. a travel time of about five weeks. It should be noted that both trips were made in early winter although Amundsen's took place considerably farther south and hence with more daylight. Moreover, much of Amundsen's route lay south of the treeline, with abundant firewood available, whereas the Norwegians' route followed a tundra coast. Further, the last $300 \mathrm{~km}$ and more of Amundsen's route lay along a well-travelled trail.

A more valid comparison would be with the sledge trip made in spring of 1901 by Leytenant $\mathbf{N}$. N. Kolomeytsev and Stepan Rastorguyev from Bukhta Kolin Archera, just southwest of Ostrov Taymyr, where Baron Toll's Zarya was wintering, to Dikson and south to Gol'chikha. Their route to Dikson was identical to the last $600 \mathrm{~km}$ that the Norwegians had to cover. Kolomeytsev and Rastorguev left Bukhta Kolin Archera on 18 April and reached Dikson on 18 May, i.e. a travel time of exactly one month (Kolomeytsev. 1902; Barr, 1981). As Urvantsev $(1974,1978)$ has stre sed, however, Kolomeytsev and Rastorguyev made the trip in spring with continuous daylight and abundant game; the Norwegians were faced with a much longer trip in early winter, with little or no daylight, when the reindeer would have migrated south and seals would have been inaccessible.

$\mathrm{Be}$ that as it may, there is no indication that Knutsen or Tessem found the prospect of such a sledge journey particularly intimidating. On 21 August 1919, when it was anticipated that Maud might get free of the ice imminently, Knutsen and Tessem moved ashore to a hut they had built, and that evening a formal farewell dinner was held on board in their honour (Amundsen, 1921). They were equipped for their journey with a tent, a light sledge built by Tessem (Wisting, 1930), five dogs, provisions and fuel for about one year, rifles, ammunition, maps of the coast, compasses, watches, and a theodolite (H. Sverdrup, 1933). Amundsen's instructions to them were that they should wait until snow and sea ice conditions were suitable for sledging, then start for Dikson, "but if in their own judgment it was not advisable to travel in the fall, they should wait until the next spring"' (H. Sverdrup, 1933:6). En 


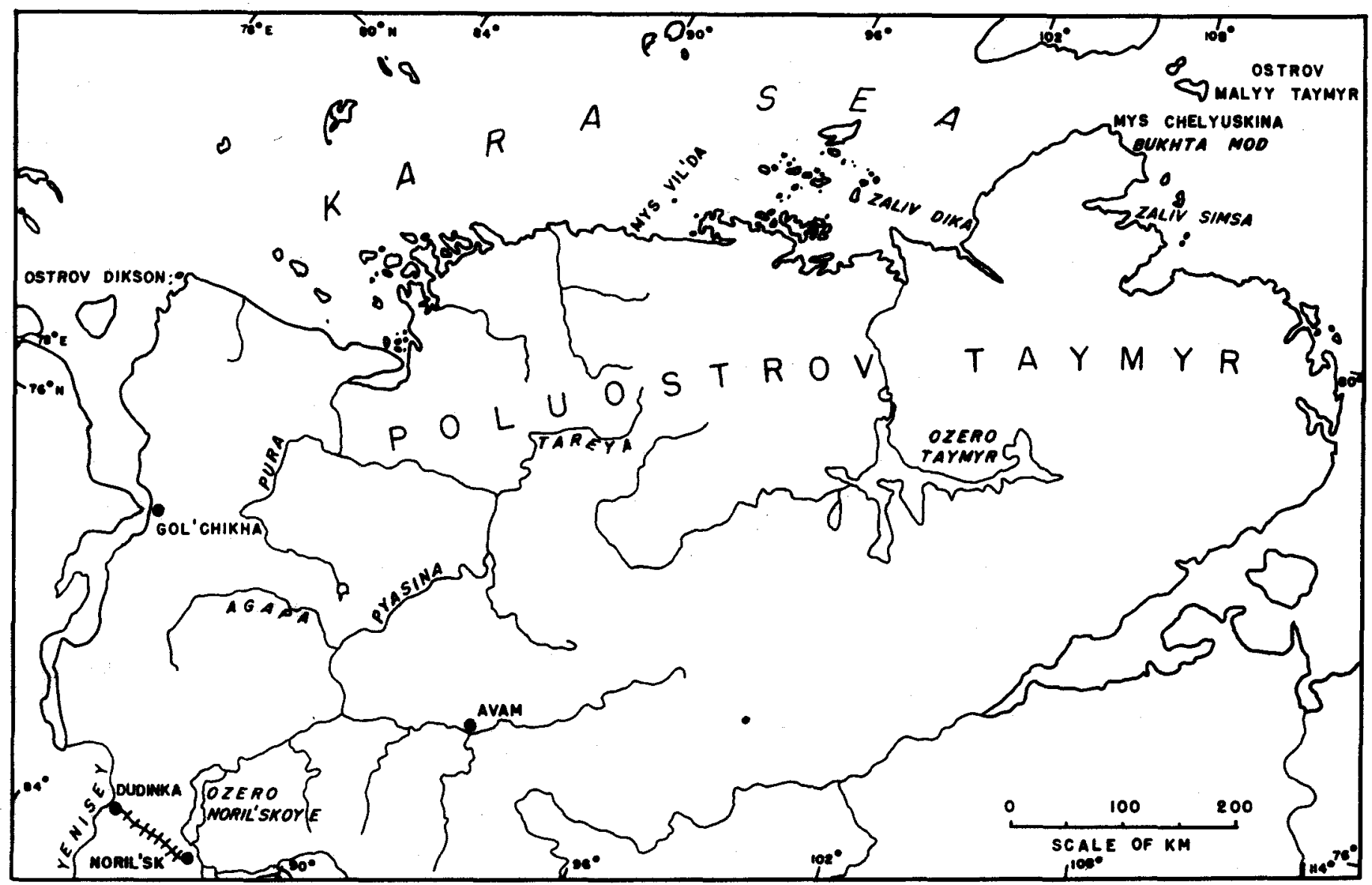

FIG. 3. Map showing route taken by Tessem and Knutsen from Mys Chelyuskina towards Dikson.

route to Dikson they were to replenish their supplies at the caches left by Otto Sverdrup in 1915 .

As it turned out, it was another three weeks before Maud finally got under way. The fast ice into which she was frozen proved remarkably stubborn and a great deal of blasting was required to liberate the ship. Tessem and Knutsen played a major part in this work, walking out from shore each day to participate. Finally, on 12 September Maud got under way, eastward bound, leaving the two men behind at Bukhta Mod (Amundsen, 1921; H. Sverdrup, 1933).

Maud did not after all begin her transarctic drift attempt from the East Siberian Sea that fall; instead she was again obliged to winter off the Siberian coast, this time near Ostrov Ayon near the mouth of Chaunskaya Guba. In December 1919 Hansen and Wisting started out by sledge from Ostrov Ayon for the wireless station at Anadyr' and in March 1920 the first news in 18 months of the Maud expedition reached the outside world. The following telegram was dispatched to Amundsen's brother, Leon, in Christiania:

Maud wintering Ayon Island,...miles east of Kolyma River, Siberia, 500 miles west of East Lake [sic], Behring Straits. All well. Tessem and Knutsen left at first wintering place in vicinity Cape Tcheljuskin east of the Kara Sea about first half October 1919. Have they reached home in safety. Roald Amundsen.

(The Times, 1920).
Even when this message arrived, the alarm was not raised immediately. Such an influential authority as Nansen expressed the opinion that the fact that the two men had not been heard from was probably due simply to the troubled political situation in Siberia (The Times, 1920). But as time passed it became evident that a tragedy had occurred and in Norway wheels were set in motion to mount a rescue effort.

\section{THE NORWEGIAN SEARCH}

With Soviet permission and acting on behalf of the Royal Norwegian -Department for Churches and Education, the veteran arctic explorer Otto Sverdrup signed a contract with the Heimen Company to conduct a search, for a flat sum of 1800 kroner (Bolotnikov, 1949). The search expedition, led by Ole Hansen, sailed from Troms $\varnothing$ aboard the auxiliary schooner Heimen on 23 August 1920. The party reached Dikson successfully, then continued east in an attempt to reach Mys Vil'da - one of the few points at which it could safely be assumed Knutsen and Tessem would have called (Urvantsev, 1978). But east of Dikson the schooner ran into heavy ice and in the vicinity of Poluostrov Mikhaylova she was forced to turn back. After a quick visit to Gol'chikha she again called at Dikson, then sailed for home on 11 September. She did not get very far, however; experiencing serious engine trouble, her captain, Lars Jakobsen, decided that it was too hazardous to at- 
tempt the remainder of the passage across the Kara Sea under sail alone. Hence Heimen returned to Dikson and her crew resigned themselves to a wintering at the Soviet weather station there.

The Norwegian government decided to make the best of this situation, and to mount an overland search expedition. On 12 October 1920 the Russian wireless operators at Dikson received the following telegram in Norwegian, addressed to their guests:

\section{Dikson, Heimen, Jakobsen.}

If wintering essential, make preparations to travel to Mys Vil'da with dogs or some other means in the spring of 1921. For this purpose you should hire or buy dogs. Establish depots in advance.

(Bolotnikov, 1949:181; Urvantsev, 1978:63).

That same day a reply was transmitted:

Telegram received. Will remain here for the winter. No news of Tessem and Knutsen. Will try to hire dogs or reindeer for an expedition. All well. Lars Jakobsen.

(Bolotnikov, 1949:181).

\section{SOVIET PREPARATIONS FOR AN OVERLAND SEARCH}

Clearly, however, Jakobsen was faced with serious practical difficulties in trying to implement his government's instructions. There was no permanent population at Dikson, other than the staff of the weather station, who possessed only one dog team. Hence there was no chance of hiring dogs or reindeer locally for a major expedition. But, unknown to the Norwegian government, wheels had already been set in motion by the Soviet authorities to mount such an expedition. Given the chaotic state of the Soviet economy and the even worse state of the transport system in the summer of 1920 , this humanitarian effort by the newly established Soviet régime is one of which it can be justly proud.

During September the hydrographic vessel Iney, bound upriver, called at Dudinka. On board was F. A. Shol'ts, Deputy Chairman of the Committee for the Northern Sea Route (Komitet Severnogo Morskogo Puti or Komseveroputi), established under the auspices of the Sibirskiy revolyutsionnyy komitet on 20 April 1920. Shol'ts was on a general tour of inspection but he had also been authorized to assist in the search for the missing Norwegians. At Dudinka Shol'ts located Nikifor Begichev and asked for his help (Bolotnikov, 1949).

There can be little doubt that there were few men better qualified to undertake the type of search mission envisaged. Begichev had been ship's bosun for Baron Toll's Polar Expedition aboard Zarya in 1900-1902 (Toll, 1909; Barr, 1981). This meant that, among other qualifications, Begichev had spent a winter at Bukhta Kolin Archera and was fully familiar with the environment of that area. Once the Russian Polar Expedition sensu stricto had been disbanded, Begichev had been a member of the small party led by Leytenant A. V. Kolchak, which in 1903 had sledged a whaleboat from Bukhta Tiksi to Ostrov Kotel'nyy and then sailed it out to Ostrov Bennetta in search of the missing expedition leader, Baron Eduard von Toll (Barr, 1981b).

But Begichev's more recent experience qualified him even more eminently for this mission. During the winter of 1914-1915 the two Imperial Russian navy icebreakers Taymyr and Vaygach became beset by ice and were obliged to winter near Zaliv Dika on the west coast of Poluostrov Taymyr (Starokadomskiy, 1976). By good fortune they were able to make wireless contact with another wintering vessel, Eclipse, commanded by Otto Sverdrup and located at Mys Vil'da (near Mys Shtellinga), and through her with the wireless station at Yugorskiy Shar and hence with St. Petersburg. Apprehensive that his ships might not be able to get free of the ice during the 1915 season, Leytenant B. A. Vil'kitskiy, Taymyr's captain and leader of the expedition, requested that a relief expedition be mounted whereby half his crews would be evacuated overland to Gol'chikha or Dudinka as a precautionary measure.

In the spring of 1915 Sverdrup and a party of Norwegians sledged from Eclipse to the icebound Russian icebreakers and then escorted 52 members of the crews of the Russian ships back to Mys Vil'da (O. Sverdrup, 1921; Starokadomskiy, 1976). In the meantime Begichev, who had settled as a trapper in the Dudinka area and had established an excellent rapport with the Nganasan reindeer herders of the Avam area, was asked by the Hydrographic Department in St. Petersburg to assemble a caravan of reindeer sledges and trek north to Mys Vil'da (Bolotnikov, 1949). After considerable negotiations Begichev was able to assemble 668 reindeer, with the appropriate number of sledges, herders, and drivers, and the caravan started north. Despite serious difficulties caused by flooded rivers, and although much of the intervening country was totally unknown, Begichev reached Eclipse on 3 July 1915 to find the Russian sailors from Taymyr and Vaygach already there. He must also have met Paul Knutsen at this time. On the evening of 15 July the entire party started south, the Russian sailors travelling on foot except for the sick, and with food and equipment loaded on the reindeer sledges. They covered some 20-25 km per day and on 2 August reached the confluence of the Tareya and Pyasina. Here by prearrangement four boats were waiting; in these the sailors travelled up the Pyasina to the Agapa River from where they again travelled overland, reaching Gol'chikha on 19 August.

The second part of Begichev's instructions specified that he should return to Mys Vil'da in case Taymyr and Vaygach were still beset in the ice making it necessary to evacuate the second half of their crews overland by the same route. Begichev reached Mys Vil'da for the second time on 15 August to find that Eclipse had already sailed. Nonetheless Begichev waited on the coast until 1 October in case the icebreakers might still need his assistance, but they too had been freed from the ice and had reached Dikson safely. By 26 October Begichev was back in Dudinka.

Given this record it was scarcely surprising that Shol'ts should have called on Begichev for assistance once more. Begichev agreed in principle, and hence it came as no surprise when, in early October, he received a wireless message from N. F. Timofeyevskiy, leader of the weather station at Dikson, 
enquiring whether he was still interested in mounting an overland search expedition. Begichev confirmed his interest but stressed that an early decision was essential to give him time to discuss the hiring of reindeer and sledges with the Nganasan reindeer herders. The outcome was a wireless message from Dikson to Komseveroputi in Omsk, dated 15 October 1921:

The Norwegian expedition searching for Amundsen's companions, now wintering at Dikson, has received orders from the Norwegian government to hire reindeer independently and to proceed to Mys Vil'da. Hansen, leader of the expedition, appeals for your co-operation to give all the instructions in your powers to Begichev in Dudinka, and to organize a reindeer expedition at the expense of the Norwegian government. Begichev is personally prepared to go but needs official instructions. Request that you be sure to telegraph response to this request. Timofeyevskiy.

(Bolotnikov, 1949:182).

Naturally nothing could be done without Moscow's approval but this telegram set the wheels of government bureaucracy in motion. Komseveroputi contacted Narkomindel (People's Commissariat for Foreign Affairs) which in turn approached the Norwegian Foreign Minister. When his consent was given, official approval was forthcoming from Moscow. On 2 December 1920 the following telegram was dispatched from Narkomindel to Omsk:

To the Siberian Revolutionary Committee (Committee for the Northern Sea Route). Via No. 5441 Narkomindel reports that it is inquiring with interest about the situation re the rescue of Knutsen and Tessem. In view of both humanitarian and political considerations the government of the RSFSR considers it essential to give appropriate assistance to Hansen's expedition aboard the schooner Heimen, which was dispatched with the approval of the government of the RSFSR. NKID also suggests that the involvement of Comrade Begichev in this matter would be extremely expedient and asks that you keep them posted as to further actions (and also as to their results) connected with the matter in hand.

(Bolotnikov, 1949:182).

Begichev had, in fact, anticipated this message, being well aware of how crucial the time factor would be if a search were to be mounted the following spring. On his own initiative he travelled to Avam to discuss the hiring of reindeer and drivers with the same headman, Kachdo, with whom he had negotiated on behalf of the Tsarist government in 1915. At first Kachdo was reluctant to commit himself and his people, especially since Begichev was unable to specify the precise route or the conditions of payment. But finally, after hours of patient negotiation Begichev was able to extract a conditional commitment, and then travelled back to Dudinka to await official authorization for what he had just done.

This came in the form of a telegram on the evening of 23 December 1920:

Dudinka, to Begichev, copy to Timofeyevskiy.

Reach an agreement through Timofeyevskiy with the Norwegians of the schooner Heimen, wintering at Dikson, concering an overland expedition in search of Knutsen and Tessem this spring. Take part both in its organization and execution as you did in 1915. You will receive assistance on the part of the Soviet Republic. Komseveroputi. No. 6328.

(Bolotnikov, 1949:183).

Until the early hours of the morning Begichev discussed the proposed trip with his friend Yegor Avanovich Kuznetsov, who would be accompanying him. Together they composed the following telegram to Timofeyevskiy:

In accordance with Komseveroputi's telegram No. 6328 I request that you enter negotiations with the Norwegians. I agree to mount an expedition to search for Knutsen and Tessem. First: I need information as to the route, provisions for the men, footwear, clothing, weapons, payment and the date of departure. Is a call at Dikson necessary; the route via there is more difficult. Second: You will provide my family with fuel, lighting and provisions during my absence. It is desirable that we complete negotiations as soon as possible; I need to depart for Avam to assemble the reindeer, prepare the sledges and find the men. Begichev.

(Bolotnikov, 1949:183).

To expedite matters, even before receiving a response to this message Begichev sent Kuznetsov with letters to Kachdo and other leaders among the Nganasan reindeer herders in the Avam area, asking them to find experienced drivers and herders, 500 head of draft reindeer, and 25 light sledges. He stressed that he would be arriving shortly himself to discuss details. On 2 January 1921 Timofeyevskiy's reply reached Dikson, outlining the outcome of his discussion with the Norwegians. Begichev was to call at Dikson to pick up two of the Norwegians, Lars Jakobsen, Heimen's captain, and, as interpreter, seaman Alfred Karlsen (Fig. 4). They would travel with him to Mys Vil'da by a route selected by Begichev. From there the further search plan would be decided on the basis of what message (if any) Knutsen and Tessem might have left at the depot there. The timetable of the expedition wold be left to Begichev but the intention was that the two Norwegians would

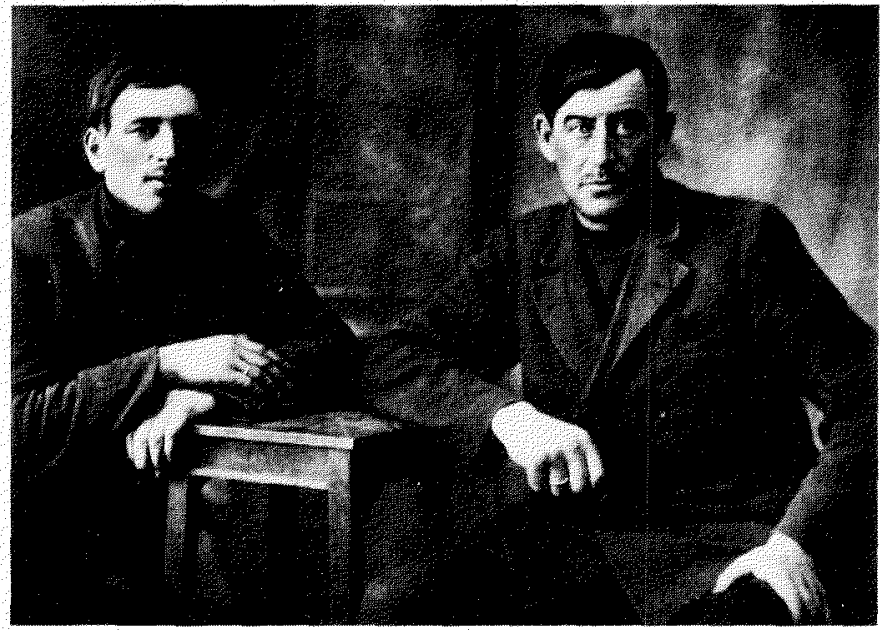

FIG 4 Lars Jakobsen (right) and Alfred Karlsen, Novo-Nikolayevsk, January 1922 
get back to Dikson prior to the start of the navigation season. Provisions, firearms, and equipment would be provided either from Heimen's stores, or by Timofeyevskiy from the weather station's supplies. Finally Begichev was asked to name his salary (Bolotnikov, 1949).

Begichev was not at all enthusiastic about making the circuitous detour via Dikson en route to Mys Vil'da, and suggested that the Norwegians come to Dudinka. For unspecified reasons Jakobsen refused, which meant that Begichev's route was considerably lengthened; worse still, it meant travelling through an area known to be almost devoid of reindeer fodder.

Begichev travelled to Avam and finalized the provisional arrangements that Kuznetsov had made with Kachdo. Price, dates, and the assembly point for 500 reindeer were settled. Begichev then hurried back to Dudinka to pick up the supplies for the trip. Here a bureaucratic error almost wrecked the entire project. The local Gubsoyuz (provincial cooperatives) agent had received orders to supply all necessary provisions but insisted on cash payment. Begichev had been allocated one million roubles to cover his expenses, to be disbursed through the local post office, but the latter did not have sufficient cash on hand. This crisis was resolved by Begichev's numerous friends in the community; workers at the wireless station, hunters, and fishermen lent him all their available cash and with it Begichev was able to buy the essential provisions and equipment.

\section{BEGICHEV'S SEARCH}

Final preparations, including frequent exchanges of telegrams, continued until well into March. On 1 April Kuznetsov set off with several sledges from Dudinka and on the 13th Begichev followed, accompanied by the third Russian member of the party, Grigoriy Kaydalov. On 20 April Begichev reached the camp of the Nganasan Chuta, near Avam, where Kuznetsov had been assembling reindeer. Thus far, however, he had managed to muster only 150 head. But once Begichev arrived and began further negotiations with Kachdo, the reindeer and drivers began to congregate. The full complement of 500 animals had arrived, when a blizzard lasting several days scattered them across the tundra and buried the laden sledges in snow. Rounding up the herd again and digging out the sledges took a further three days. But finally on 3 May the caravan got under way (Fig. 5).

Begichev had decided to divide the caravan into two detachments; the first group, led by Begichev and consisting of Kuznetsov, Kaydalov, six drivers, and 300 reindeer, set a course for Dikson. The other, consisting of the Nganasany Chuta, Konde, and Munka, with 200 reindeer, headed north down the Pyasina and across the Khrebet Byrranga to Poluostrov Mikhaylova where they were to wait for the first group.

On 19 May, some $50 \mathrm{~km}$ from the mouth of the Pura, Begichev again divided his detachment. With 107 animals and ac-

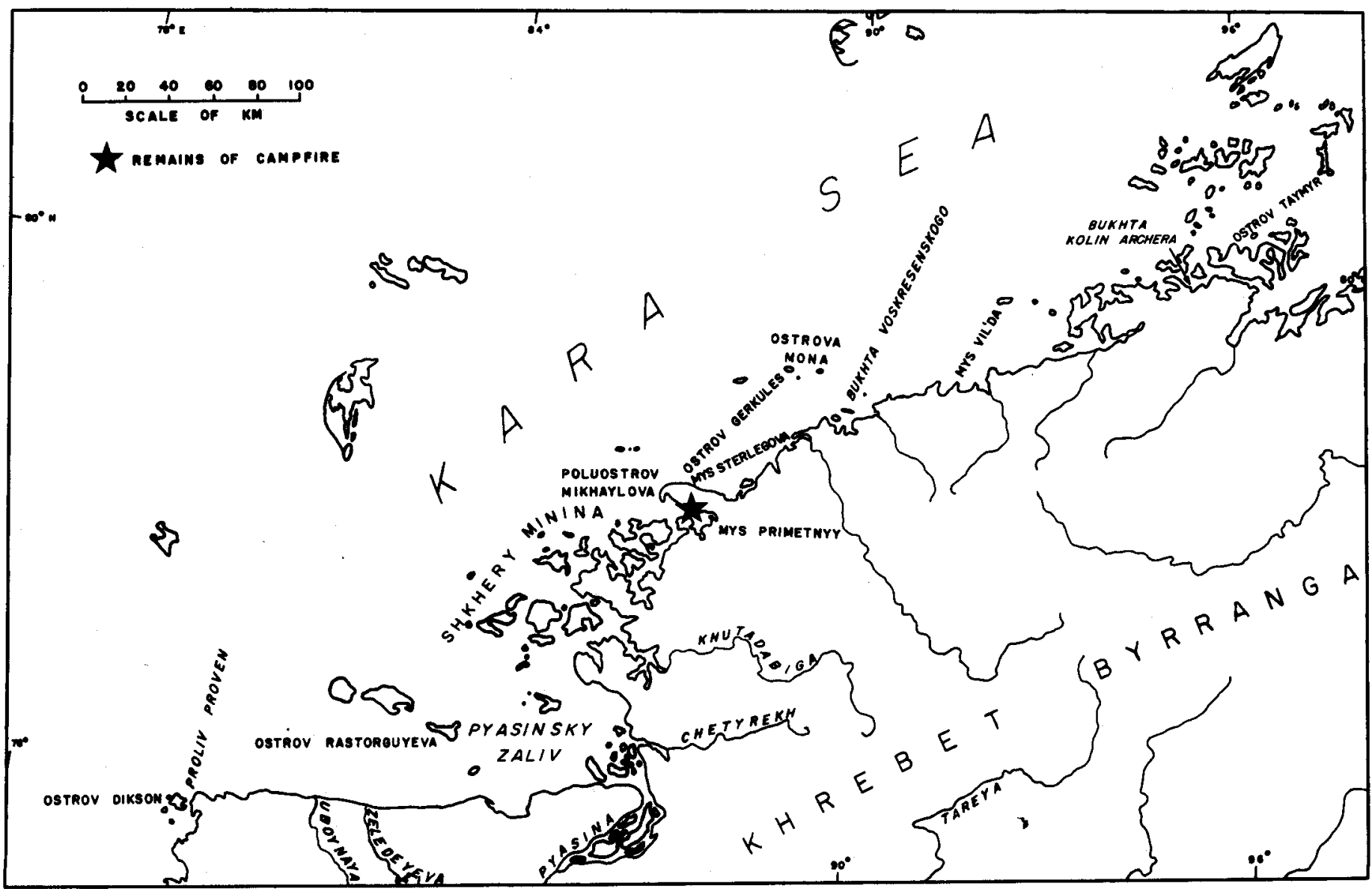

FIG. 5. Map showing area of searches, 1921 and 1922. 
companied by Kuznetsov, Kaydalov, Kite, Muzha, and Lopsher, he continued his way on towards Dikson. Yuraka, with the remaining drivers and reindeer, was to proceed to the mouth of the Pura (i.e. its confluence with the Pyasina) where they were to rest and fatten their weakened animals, and wait for Begichev to meet them.

The trip to Dikson was plagued by blizzards and lack of fodder. Almost daily Begichev was forced to abandon weakened animals on the tundra, keeping a careful note of their owners so that they could be reimbursed appropriately. Some sacks of lichen for fodder had been brought from Avam but by 27 May this standby was exhausted. A typical entry in Begichev's diary reads as follows:

30 May, Monday. Blizzard all night. The wind has shifted and is now blowing from the WSW. At 3 o'clock we began catching the reindeer; at 5:30 headed off NW $77^{\circ}$. Stopped at 10.00. We had travelled a total of 3 hours; covered 17 versts [approximately $17 \mathrm{~km}$. Abandoned 9 reindeer along the way. A very severe blizzard developed into a gale. Our tent ripped and we could barely hold it. Tent torn in several places.

(Bolotnikov, 1949:186).

To add to Begichev's problems, Kaydalov appears to have been less than a shining asset. First of all he lost the party's only axe at Ozero Sholbota; on being reprimanded by Begichev he set off back to the lake on foot to try to find the axe. Apart from the real danger of his getting lost in a blizzard, this meant that Muzha had to be sent back to find him, and the entire party was delayed for a full day. Then on 31 May Kaydalov managed to break the only thermometer.

Finally, on 4 June 1921 Begichev and his party reached the weather station at Dikson. In a month they had covered some $600 \mathrm{~km}$ from Avam; along the way 42 reindeer had been lost. They could not afford the luxury of a long rest at Dikson, however strong the temptation must have been; they had to get to Mys Vil'da before snowmelt was too far advanced. Hence, on 8 June, accompanied by Lars Jakobsen and Alfred Karlsen, Begichev's group started eastward. Kaydalov was left at Dikson.

Initially they headed east along the coast but then, in order to rendezvous with Yuraka at the mouth of the Pura, they had to swing inland toward the southeast. The reason for making the rendezvous here, rather than on the coast, was that Kachdo had sworn that there was absolutely no reindeer fodder along the coast - which was far from being the case. Apart from the considerable unnecessary mileage involved, Begichev and his party had to cross a vast area of tundra devoid of fuel, whereas the coastal route would have provided driftwood. As if to emphasize this difference, at the first campsite, only $16 \mathrm{~km}$ from Dikson, the primus stove blew up while Jakobsen was brewing tea. Fortunately nobody was injured and the blaze was quickly extinguished.

Despite persistent rain and melting snow the party made good progress, although the reindeer were in poor conditoin and steadily weakening. On 21 June they reached the Pyasina near the Pura confluence, having covered some $240 \mathrm{~km}$ in 13 days. A day's search located Yuraka with his herd of fresh reindeer.
The exhausted animals were left there in Muzha's charge while Begichev and his party continued eastwards with fresh animals, having first established a depot of provisions and firewood for their return. On 6 July the party reached the Dolgiy Brod River [now the Chetyrekh (Troitskiy, 1977)]; a further group of 100 reindeer was left there in the charge of Bocha, while Begichev, Kuznetsov, the two Norwegians, and the other herders began crossing. In the middle of the river some of the reindeer became tangled in their harnesses and for about an hour the men waded about waist-deep in the icy water, disentangling the frightened animals. Since there was no firewood available, on reaching the other banks they chopped up one of the sledges for fuel to dry their clothes and warm themselves.

On 8 July, with the reindeer wallowing belly-deep in wet, soft snow, the party reached the Tamara River [now the Khutadabiga (Troitskiy, 1977)] where Chuta should have been waiting with his 200 reindeer. After several days of searching in steady rain and thick fog, the men located the herd on the 12 th.

The two Norwegians had impressed Begichev as being tough, hardy, and reliable. They helped Begichev and the herders in catching the reindeer in the mornings, a task demanding great agility. Jakobsen regularly supplied the party with geese and, on occasion, wild reindeer. But this last lap had tested them severely and Jakobsen now suggested that they rest here for a few days. Reluctantly Begichev had to deny this request; he realized only too well that the snow would soon disappear completely and that hence every hour was precious.

Once again the best animals, this time numbering 111 , were selected and the remainder were left at the Tamara under the care of Kita, Yuraka, and Chuta to rest and await the return of the main party. On 16 July Begichev, the Norwegians, and the rest of the herders pushed on eastwards; by now the travel conditions were so rough that even the fresh reindeer began to collapse. On the 19th they reached Bukhta Voskresenskogo where Begichev was surprised and pleased to find a stack of sledges which he had left there in 1915. Mys Vil'da now lay only $20 \mathrm{~km}$ ahead. Leaving most of the herd with the herders, on the night of 27 July Begichev, Kuznetsov, the Norwegians, and Konda covered this final distance.

Nikifor Alekseyevich immediately recognized the cape, with the tall, conspicuous cairn built by Sverdrup in 1915 . Strewn all around were boxes from the supply depot, evidently scattered by bears. On examining the cairn Begichev found a tin can containing a letter; it had been written in English with an indelible pencil on thick notepaper with the letterhead of the Maud expedition. Jakobsen and Karlsen knew enough English to decipher the gist of the message. It read:

\section{Maudexpeditionen.}

Two men of the Maud expedition, travelling with dogs and sledge, arrived here the 10th of November, 1919. We found the cache of provisions deposited at this point in much damaged condition, especially all the bread being mouldy and spoiled by sea water showing that heavy seas have been washing over this point. We have moved the cache further in on the land about 25 
yards and completed our stock of provisions for $\mathbf{2 0}$ days from the store here. We are in good condition and going to leave for Port Dickson today. Nov. 15th, 1919. Peter L. Tessem, Paul Knutsen.

(Bolotnikov, 1949:191).

Begichev and his companions finally had some firm information on which to base the remainder of their search. Before starting the long trek along the coast to Dikson on the morning of the 28th, they left two letters in the cairn, one written by Jakobsen in Norwegian, the other in Russian by Begichev; both gave details of their visit. Begichev placed his note inside one addressed to Otto Sverdrup that he had left there six years earlier. Taking some provisions from the cache, they started west. On the way back to Bukhta Voskresenskogo, just west of Mys Vil'da, Konde's sledge broke through the ice; one reindeer drowned but Konde, the sledge, the other nine reindeer, and most of the food were saved through the efforts of Begichev and the Norwegians. This incident served to emphasize the hazards which Knutsen and Tessem had also faced on this same coast, but at a much more inhospitable time of year.

On 30 July the entire detachment started back west with the aim of following Knutsen and Tessem's route as closely as possible. While Begichev reasoned that the Norwegians would have followed the coast fairly closely, in order to ensure a supply of driftwood for fuel, he was also certain that they would frequently have cut across bays from headland to headland. Hence the strategy he adopted was to send the main party via a fairly direct route, in general parallel to the coast but striking the heads of the bays at a tangent, while ancillary parties searched every kilometre of the shores of the projecting headlands on foot. A glance at the map (Fig. 5) will reveal a fairly simple coastline as far as Poluostrov Mikhaylova, making execution of this strategy fairly simple. But beyond that point, the labyrinthine islands and channels of the Shkhery Minina made it impossible to cover the entire shoreline of every island, and since Begichev had no indication of the route the Norwegians might have followed through the archipelago, he would have needed a large share of luck to retrace their route even approximately. To emphasize the problem, it may be recalled that during their sledge trip along this same coast Kolomeytsev and Rastorguyev had cut directly across Pyasinskiy Zaliv in a three-day trip away from land, skirting the western tip of Ostrov Rastorguyeva en route (Kolomeytsev, 1902; Barr, 1981).

Aware of what he was facing, and anticipating a protracted search, Begichev rearranged his relief herds of reindeer to achieve the best possible support. He sent Konde to Chuta's camp on the Tamara River with orders to Chuta to move his rested animals to Gora Minina. Meanwhile Boche and Kite were to relieve Muzha, still waiting at the mouth of the Pura, and to bring his herd north to the coast at the mouth of the Pyasina. With Konde he also sent letters and telegrams for despatch to Omsk, Moscow, and Norway.

The next significant find was made by Jakobsen on 3 August, about $6 \mathrm{~km}$ from Mys Sterlegova and about $90 \mathrm{~km}$ west of Mys Vil'da. This was an abandoned sledge, totally dif- ferent from those built by the local Nganasany, but not unlike a Norwegian design. There were several features which suggested that it had been made by relatively inexperienced craftsmen from materials which happened to be available: the uprights were fastened with thin steel cable, and copper tubing had been used for braces between the uprights. The same copper tubing had been used for the bow at the front of the sledge (Urvantsev, 1974; Shparo and Shumilov, 1975). Shparo and Shumilov (1975) have pointed out that it is extremely unlikely that such experienced travellers as Knutsen and Tessem would have used metal fastenings in making a sledge; it is well known that this leads to excessive wear on the adjoining wooden parts. However, as with so many other aspects of the mystery, this is something which sould be readily solved by a scrutiny of the original records of the Maud expedition, since it seems likely that somebody would have noted the details of the sledge that Tessem built.

Since he was on foot, Jakobsen was unable to retrieve the sledge, but Kuznetsov was sent with a boat to recover it. Unfortunately a strong wind endangered his overladen little craft and he was obliged to abandon the sledge again. He left it on a conspicious hill where it was rediscovered in 1934 by the leader of the polar station at Mys Sterlegova, K. M. Zvantsev (Shparo and Shumilov, 1975).

The search continued. All the bread and canned goods were long since exhausted and the party was almost entirely dependent on hunting ducks, geese, and wild reindeer; the latter were fortunately quite abundant. On the foggy morning of 10 August Jakobsen and Karlsen were walking along the west side of a cape they referred to as Mys Primetnyy [more recently it has been established that this cape in fact lies $40-50 \mathrm{~km}$ west of Mys Primetnyy (Shparo and Shumilov, 1975, 1982)]. Near the tip of the cape they found traces of three fires on the shore, spaced at relatively close intervals. Although there were no clues to go by Jakobsen felt convinced that the fires had been lit by Knutsen and Tessem. He explained their close spacing by the fact that the two men must have been in poor shape and had had to stop frequently to build fires to rest and warm themselves.

Meanwhile Begichev was investigating the shores of a nearby bay. Since what he found has given rise to endless speculation it is worth quoting his report to Komseveroputi (as relayed by Bolotnikov) verbatim:

I walked all around Glubokaya Bukhta and, via the west shore, emerged at high, sheer Mys Zemlyanoy. I walked northwest across the cape. Soon the cape ended. On its western side there is a bay which runs deep into the mainland to the south for 40 versts [ $40 \mathrm{~km}$ approximately]. I headed north. On a spit I spotted some charred firewood and walked over to it. There lay the burned bones of a man and many buttons, buckles, nails and something else: a cardboard shotgun shell and several rifle shells. I gathered them together and started back to the tent with them.... When I reached the tent the captain and Alfred had still not returned. I unpacked the items I had found. The shells turned out to be of Norwegian military pattern, dated 1915 . Then I realized that one of Amundsen's companions had died here.

(Bolotnikov, 1949:194; Chubakov et al., 1974:74). 
A more thorough search next day revealed various other items in and around the fire: the remains of a pocket barometer, a penknife, parts of a spectacle frame, a French coin, buckles, buttons, and other small items.

\begin{abstract}
We concluded that these were the bones of one of the men we were seeking. We assume that during their journey on foot during the dark period, under very cold, blizzard conditions, they had lost their way and ended up at this deep bay. One of them died and, not being able to bury him, his comrade cremated him on the fire so that animals would not dismember the corpse; he himself then, apparently, headed across the bay towards Mys Mikhaylova.
\end{abstract}

(Bolotnikov, 1949:194; Shparo and Shumilov, 1975:19).

Jakobsen took photographs of the site as they had found it, then they dug a grave and deposited the bone remains and ashes from the fire in it. They piled rocks over the grave mound and erected a cross. To it they fastened a piece of a metal sledge runner shoe, on which Kuznetsov had scratched an inscription. Some $10 \mathrm{~m}$ southwest of the cross Jakobsen and Karlsen sank a 2-m post into the ground and buttressed it with rocks. On it about $1 \mathrm{~m}$ from the ground they carved: $\mathrm{LJ}$, AK 11.8.1921 (Shparo and Shumilov, 1975, 1982). Twenty metres west of the grave Begichev erected his own marker, a driftwood post in which he carved his initials and the date with an axe. This last marker was found, toppled, by a search party led by D. I. Shparo and sponsored by the newspaper Komsolol'skaya Pravda in August 1974 (Fig. 6) during the second of six field seasons devoted to searches for historical relics in the Soviet Arctic (Shparo and Shumilov, 1982).

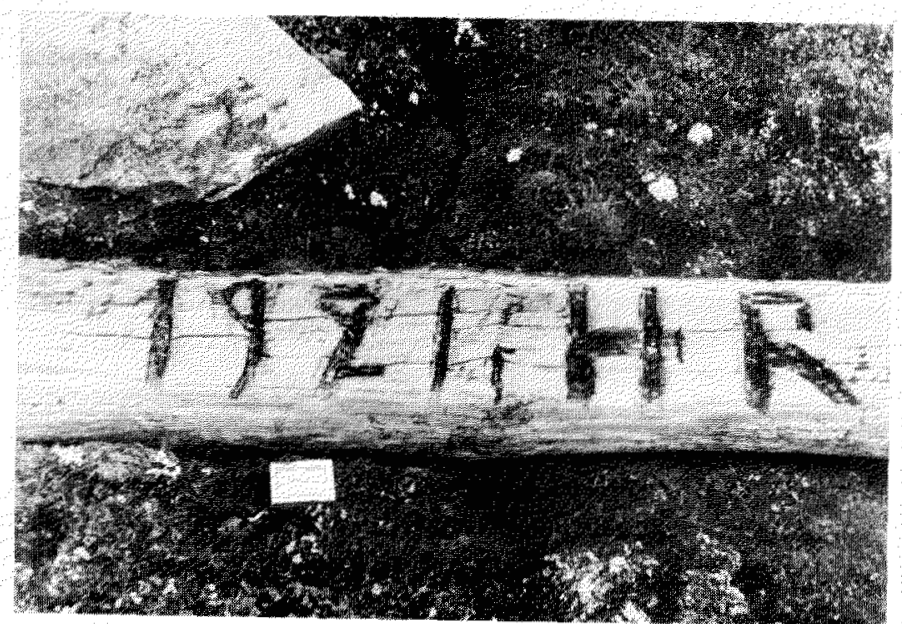

FIG. 6. The post with Begichev's initials and the date, erected by nim at Mys Primetnyy in 1921, as discovered in 1974.

Resolved to find traces of the other missing Norwegian, the party pushed on southwestward searching as much of the coast as they could. On 25 August they reached what they took to be the main channel of the Pyasina which they knew would be a formidable obstacle; they began crossing on the 27th, the men and belongings in two boats and the reindeer swimming. Almost predictably, the reindeer again became tangled in their harness and the men had to leap into the freezing water to free them. But finally the entire party was safely across. Any feel- ing of achievement was premature, however; three days later they came to an equally wide channel. For those three days they had been crossing an island in the Pyasina estuary. During this second crossing two reindeer drowned. Four kilometres farther on they were faced by yet another major channel, in fact the main channel of the river. They crossed it safely, too, but then prolonged blizzards began and since any trace of the missing Norwegians would now be hidden by snow, Begichev reluctantly abandoned the search.

At this critical point even the hunting failed them and they had to start slaughtering some of their own reindeer. On 8 September, however, Begichev and Jakobsen shot six wild reindeer, and Kuznetsov and Karlsen caught a large number of fish. Cheered by this success, they began searching for Muzha's herd, but after two days had seen no signs of it. At this point Begichev decided to abandon any attempt to reach Dikson that season. Leaving the herders to work their way back south with the herd at their own pace, he, Kuznetsov, and the Norwegians located a boat which had been left at a prearranged spot and set off, rowing, up the Pyasina. Near the mouth of the Pura they found a Nganasan encampment but nothing could induce the herders to risk their animals on a forced march to Gol'chikha. Had some of them volunteered, Jakobsen and Karlsen could have reached Gol'chikha in time to catch the last steamer upriver.

Instead Kuznetsov and Karlsen were sent back to meet their own herd of animals, slowly working its way south. Selecting some of the best animals, they finally parted from their Nganasan companions for the second time on 12 September. Exactly a month later, on 12 October 1921, the party reached Dudinka. By Begichev's calculations they had covered 2346 $\mathrm{km}$ for a total expenditure of 125 head of reindeer, 92 of which had been abandoned, exhausted.

\section{JAKOBSEN AND KARLSEN HEAD FOR HOME}

At Dudinka news awaited them which made Jakobsen and Karlsen very glad of their decision not to try to reach Dikson. Once the ice had gonesout, Heimen had sailed for Norway on 1 August, reaching Troms $\phi$ on 20 August; it had been decided that her charter fee would have been exorbitant had she waited for them any longer. Thus Jakobsen and Karlsen had to wait at Dudinka until the overland winter sledge route was established; in the interim they stayed with Begichev and his family. Finally on 11 November the two Norwegians started south by post sledge, reaching Krasnoyarsk on 30 December.

Letters that have survived in the archives demonstrate clearly that Soviet officials in Krasnoyarsk went to considerable lengths, within the limitations imposed by Siberia's battered economy, to make the two as comfortable as possible. Thus a letter from the Krasnoyarsk division of Komseveroputi reads:

\section{To the Chairman of Komseveroputi.}

The men sent by the Norwegian government to search for Amundsen's two companions who disappeared without trace on his expedition to the North Pole, Lars Jakobsen, captain of the schooner Heimen, and his interpreter, Alfred Karlsen, arrived 
in Krasnoyarsk on 30 December, on their way back to their own country. I have taken every measure to assist them so that they may have a successful journey from here. Having housed them in the office of the Hydro Detachment Centre, and having supplied them with two cans of corned beef $(71 / 2 \mathrm{lb}$ each) and 3 lb of hardtack, I turned for assistance to the chairman of the Yeniseysk gubispolkom [provincial executive committee] who, for his part also gave orders that they be given every possible assistance. He provided them with free transport to Novonikolayevsk [now Novosibirsk] in the car of the head of the Sibmilitsiya, supplied them with money ( 500 th. roubles) on account of Sibrevkom, two sheepskin coats, which they needed, foodstuffs ( $10 \mathrm{lb}$ of bread, $5 \mathrm{lb}$ smoked meat, $3 \mathrm{lb}$ butter, $1 / 4 \mathrm{lb}$ tea, $1 / 2 \mathrm{lb}$ tobacco and two boxes of matches) and, finding their accommodations in the office inconvenient, provided them with quarters in the Dom Krest'yanina hotel. As foreigners unfamiliar with our procedures they were provided with complete assistance by the Detachment's headquarters to carry out any busy formalities; and finally officials of the detachment tried to show them hospitality on their own personal initiative.

Since I consider it absolutely essential to render every assistance now and in the future to these representatives of Norway, a friendly power, I request your orders as to their expeditious and suitable transport back home.

Head of the Division's Hydrographic Detachment, Neupokoyev.

Acting Head of Hydro Detachment's Centre, Drizhenko

(Bolotnikov, 1949:198-199).

From Novonikolayevsk the two Norwegians travelled to Omsk and then on to Moscow. Prior to leaving Omsk they were each supplied with a letter of introduction. Jakobsen's read as follows:

This letter of introduction is given to the Norwegian citizen Lars Jakobsen in recognition of the fact that, on orders from the Norwegian government he sailed from the Norwegian city of Troms $\phi$ on 12 August 1920 as captain of the schooner Heimen on a polar expedition to the Siberian shores of the Arctic Ocean in search of Amundsen's companions who disappeared without trace on his expedition to the North Pole. Having spent the winter on the Russian island of Ostrov Dikson, in the summer of 1921 Jakobsen completed the mission entrusted to him, after which he travelled overland via Turukhansk, Yeniseysk and Krasnoyarsk to Novonikolayevsk where he reported to the Committee for the Northern Sea Route.

At the present time Jakobsen is travelling to the city of Moscow, to the People's Commissariat for Foreign Affairs, in order to proceed thence to Norway.

In accordance with discussions between the Russian Soviet government and the government of Norway, all Soviet institutions and officials are obliged to provide the bearer of this letter with every assistance on his journey.

(Bolotnikov, 1949:199).

The two men reached Moscow on 17 January 1922 (Jakobsen, 1922) and returned to Norway shortly afterwards; the impressive Soviet-Norwegian search for the two missing men was over. While some questions had been answered, many still remained unresolved, not the least of them being the fates of the mail and documents, and the second Norwegian, assuming that one of them had died at Mys Primetnyy.

\section{URVANTSEV'S VOYAGE DOWN THE PYASINA}

Both questions would be answered, almost accidentally, the following summer. In 1922 geologist N. N. Urvantsev, who in 1920 had discovered the massive copper-nickel deposits at Noril'sk, was given instructions to investigate the navigability of the Pyasina with a view to exploiting those deposits (Urvantsev, 1974). It was felt that a railway across the $100-\mathrm{km}$ expanse of swampy, treeless tundra to Dudinka would be exorbitantly expensive to build (although it was later accomplished); on the other hand the Noril'skaya River flowed within $12 \mathrm{~km}$ of Noril'sk, debouching into Ozero Pyasinskoye, and would appear to provide a feasible transport route if the Noril'skaya and Pyasina had sufficient depth.

Urvantsev travelled down the Noril'skaya and around Ozero Pyasinskoye during the winter of 1921-22, surveying and sounding as he went; both bodies of water turned out to be navigable, with a minimum depth of $1.5 \mathrm{~m}$. Also during that winter he transported by reindeer sledge a small fishing boat, a small rowboat, two tents, and provisions from Dudinka to Vvedenskoye on the Pyasina, $25 \mathrm{~km}$ below the lake (Urvantsev, 1974, 1978). By modern standards the provisions were incredibly limited in amount and variety: hardtack, rusks, oatmeal, and brick tea. Urvantsev makes the illuminating comment with regard to general living conditions in Siberia at that time: "There was very little butter or sugar anywhere at that time; we certainly did not have much with us" (Urvantsev, 1978:40). The party was to rely heavily on hunting, and to this end had a shotgun and two rifles.

The group consisted of Urvantsev, topographer Sergey Dmitriyevich Bazanov; student naturalist Boris Nikolayevich Pushkarev; and in case they returned by sea, Ivan Vasil'yevich Borisov, the radio operator from Dudinka, formerly a member of the crew of the icebreaker Vaygach. Having heard in early May of the impending expedition, Nikifor Alekseyevich Begichev let it be known that he would like to participate, in order to reconnoitre the hunting and trapping potential of the area around the mouth of the Pyasina, with the idea of possibly setting up a hunting camp there. Although a fifth member was not absolutely essential Urvantsev welcomed Begichev as a person with firsthand experience of the country and with an excellent rapport with the local people.

The party set off downstream from Vvedenskoye on 15 June 1922 (Urvantsev, 1974, 1978), making careful geological and topographic surveys and taking regular soundings as they went; they reached the river mouth on 29 July, having covered a distance of over $800 \mathrm{~km}$ in about six weeks. The river proved to be navigable throughout this distance. Next day they erected a large driftwood $\log 8 \mathrm{~m}$ long to serve as a beacon marking the navigable channel across the bar at the river's mouth (Bolotnikov, 1949; Urvantsev, 1978).

\section{AMUNDSEN'S MAIL IS FOUND}

After a short rest, on 2 August the party put to sea in their small boat, planning to follow the coast west to Dikson. Urvantsev conscientiously made frequent stops to check the bedrock geology, especially when he spotted quartz veins in the 
outcrops, since there was always the possibility of their being gold-bearing. On 9 August, near the mouth of the Zeledeyeva, at $73^{\circ} 38^{\prime} 22^{\prime \prime} \mathrm{N}, 83^{\circ} 12^{\prime} 40^{\prime \prime} \mathrm{E}$ (Bolotnikov, 1949) some white objects were spotted among the shingle on the beach; suspecting they might be quartz boulders Urvantsev swung the boat in to shore (Urvantsev, 1947, 1978). To everybody's amazement the white objects turned out to be scraps of paper: torn pages from notebooks, exercise books, and documents, all written in English. Urvantsev's latest description of the find is the most comprehensive available:

They were all scattered along the shore zone for a distance of about $10 \mathrm{~m}$. They included: 1) a partially demolished, saturated pocket calendar "The Excelsior Diary", for 1903 with a photograph, of which only the first part was filled. Although it had been completely soaked it was still possible to read the writing; 2) a similar diary for 1904 , partially torn up. Some of the pages had fallen out and were lying around; others had possibly been lost completely. This diary too was badly soaked; in places the letters had run and it was impossible to read the writing; 3) fragments of pages of letters, printed documents etc. lay scattered along the shore in disarray; 4) three exercise books filled with writing, and partially torn up so that individual pages lay scattered around. We collected all this paper and packed it into a parcel.

A little above the shore zone, amongst the driftwood which had been cast ashore we found something like a cache made of wood and arranged like a cage; it had been destroyed and its contents had been scattered around. Here we found two parcels sewn in waterproof material, each about $20 \times 18 \times 10 \mathrm{~cm}$. On one was written in English: "Director L. A. Bauer, Terrestrial Magnetism Division, Carnegie Institute, Washington." On the other: "Mr. Leon Amundsen, Christiania. Mail, manuscripts, photographs, maps, sketches." It now became clear to us that this was the mail which Roald Amundsen had sent from Bukhta Mod with the members of his expedition, Tessem and Knutsen, to Norway in the fall of 1919.

Apart from the parcels there turned out to be among the driftwood: 1) a mouldy pocket purse containing 53 roubles in Tsarist money, 25 roubles in the banknotes of the Arkhangel'sk White Russian "government", seven silver and three copper Norwegian coins; a card with Tessem's name; five of Roald Amundsen's visiting cards with a message (three in English and two in Russian): "Dear Sir, please provide all possible assistance to Mr. P. L. Tessem in sending telegrams and in countinuing his journey with the mail to Norway'; a page with the address and card of an American company; 2) a damaged boat's compass in a half-demolished wooden case; 3) a oneminute field theodolite in a battered case; 4) a half-rotten leather travelling bag with bandages, gauze and two rolls of film; 5) a tin can, about $1 \mathrm{~L}$ capacity, with remains of kerosene; 6) an empty, half-broken tank; 7) damaged, rusted binoculars, opera-glass style; 8) one aluminum and two iron pans, somewhat dented; 9) a folder, chewed by mice and almost rotted, containing blank paper, photographs, clippings from newspapers and two flags, Norwegian and American; also stowed in here were a drawing curve and a protractor; 10) a mercury thermometer in a brass case; 11) scattered buttons, thread, small buckles, etc., and also a rusted safety razor; 12) fragments of Jaeger underwear, half-rotted and torn; a Finnishstyle sheepskin hat with a leather crown; 13) fragments of waterproof fabric with rings sewn at the edges; probably the depot had been covered with this fabric to protect it from the rain; 14) a broken basket from a ski pole; 15) a rusted set of drawing instruments in a rotting case; 16) tattered woolen stockings and torn hand-made sealskin slippers.
Farther west along the coast, $400 \mathrm{~m}$ away, we found a torn, empty cover made of waterproof fabric, identical to the material on the two packages discovered earlier. On the wrapping one could still make out: "Mr. Leon Amundsen, Christiania." Farther on, home-made sealskin leather soles lay scattered around. There were no traces of a campfire which would have indicated that the people had stopped here for a relatively prolonged period. Nor did we find any notes which might have told us when, why and by whom all this property had been left here. The empty cover left no doubt that this was the remains of a third package, which had been torn apart at some time. Its contents had been scattered along the shore in disarray, and had now attracted our attention.

The cache we had found was located about $120 \mathrm{~km}$ from Mys Vkhodniy at the mouth of the Pyasina, and $1 \mathrm{~km}$ east of the mouth of the Zaledeyeva, where astronomical point No. 3, determined by Kolomeytsev, member of E. V. Toll's expedition in $1900-1902$ is located. We collected all the papers, parcels and items of equipment and packed them up for dispatch via Narkomindel to Norway.

(Urvantsev, 1978:54-55).

The torn package, the demolished cache, and claw marks on several items all indicated that a bear had stumbled on the depot and pulled it apart. From the way in which most of the papers lay scattered in the surf zone, where the first heavy storm would have washed them away, Urvantsev deduced that the bear had pulled the cache apart within the past few weeks. Of course, had it not done so, he would certainly not have spotted the cache from the boat as it cruised alongshore.

With this discovery of Amundsen's mail one more question was answered, but several more problems were posed. Clearly at least one of the Norwegians had struggled this far but the fact that he (or they) had abandoned the mail and scientific results - the raison d'être for the entire trip - appears totally baffling.

Urvantsev and his men gathered together all the mail, documents, and equipment and stowed them aboard their boat, then on 10 August continued west. On the evening of the 12 th they pitched camp at the mouth of the Uboynaya, only $60 \mathrm{~km}$ from Dikson. Some dilapidated huts stood on the right bank at the river mouth, and carefully stowed on the beams in one of them was perhaps an even more surprising discovery: two pairs of skis, in perfect condition, with the trademark of the Norwegian company "Hagen and Co." They also found a reindeerskin sleeping bag and some manila cord, but no traces of a campfire (Bolotnikov, 1949; Urvantsev, 1974, 1978). This discovery again poses several questions: if one of the Norwegians had died back at Mys Primetnyy, why would his companion have dragged the extra pair of skis all this distance? And moreover, what drastic situation would have made Norwegians abandon their skis?

That night at Mys Polyniya Begichev stumbled on something which had no connection with the missing Norwegians but was of enormous historical interest. Near the ruins of a cairn a wooden board, moss-grown and partly rotted, lay on the ground. The underside, however, was still quite fresh and on it was carved, in Cyrillic script, the inscription: "1738, August 23. Past this cape, named Mys Yenisey Severovostochniy, Navigation Officer Fedor Minin headed east 
aboard the boat Obi-pochtalon'; latitude $73^{\circ} 14$ 'N" (Begichev, 1949:203, Urvantsev, 1978:55). This was a fascinating relic of that amazing endeavour by the eighteenth-century Russian Navy to explore and chart the Northern Sea Route, the Great Northern Expedition of 1733-1743 (Belov, 1956).

On 14 August Urvantsev and his companions reached the weather station at Dikson without háving found any further traces of the missing Norwegians. The plan was to wait for the steamer, which was expected imminently with the relief crew for the weather station. But then a message was received from Dudinka to the effect that the steamer would not be coming after all and that the present weather-station staff would have to stay at 'Dikson for at least another year. It also meant that Urvantsev and his party would now have to return south through their own efforts. With a prolonged continuation of their boat trip ahead, Urvantsev sent Begichev, Bazanov, and Pushkarev across to the mainland to hunt reindeer in order to provide fresh meat for their journey. Hence on 28 April the three men crossed Proliv Proven to the mainland by boat while Urvantsev stayed behind to write up his journal and pack his things. Within the hour the three men were back with startling news; they had found a skeleton, probably that of one of the missing Norwegians.

\section{THE SKELETON}

Along with station leader Nikolay Vasil'yevich Lomakin, Urvantser went back with the others to their grisly find. The skeleton lay within sight of the weather station buildings across the strait, only $3 \mathrm{~km}$ away. Urvantsev's description is as follows:

The man lay on a high shore $4 \mathrm{~m}$ from the water. The rocks were steep basalts, polished by ice. The remains were already skeletal, lacking hands and feet, which had probably been gnawed off by foxes. Only on the crown of the head had any skin survived. In the lower right jaw the last molar had been filled. The skeleton was dressed in two Jaeger sweaters and a blue flannel shirt with pockets. These were all tucked into fur pants which were held up by a leather vest sewn to the pants. There was no hat on the head. On the right foot were the remains of a sealskin boot. Below the waist only fragments of clothing remained. The sweaters were almost intact but the flannel shirt had rotted on the chest. On top the skeleton was clothed in canvas overalls of which only the sleeves had survived intact; only tatters of it remained on the torso. Close to the dead man, lower down the slope, lay a woolen mitten. Off to the left lay a scarf, torn in half, and to the right a ski pole, broken in several places and fastened with twine. Two metres up the slope lay a hunting knife. The thin end of the blade was bent. In the pockets of the flannel shirt we found rifle shells, a box of matches, a penknife and some little scissors. There were no documents. Near the waist lay a metal pocket watch. On the inside of the lid was engraved in English: "Zieglar Polar Expedition. To Peter L. Tessem, ship's carpenter, S. Y. America. In gratitude of his loyalty in volunteering to remain at Camp Abruzzi, 1901-1905. From Anthony Fiala and the estate of Wm. Ziegler." On a thong around the waist hung a whistle and a wedding band with the words "Din Pauline" engraved inside. There were no skis and no rifle nearby. The dead man lay on his back, on the ground, but immediately beneath his feet, the smooth rock slope started. The arms were stretched out beside the body, the left leg was straight, but the right leg was bent under somewhat.

(Urvantsev, 1978:56-57).

From the facts thus presented Urvantsev (1978) has argued that the dead man's position, i.e. on his back, but with a leg bent under him, would indicate a sudden, violent death. The body was not sheltered, and Urvantsev has logically pointed out that, if resting, the dead man would have been in the lee of a rock or cliff. The body lay at the foot of a smooth, steep rock slope, leading Urvantsev to assert that the man slipped on the smooth, possibly icy rocks, slid down the rock face, and cracked his head on a rock. If knocked unsconscious he could quickly have frozen to death. Urvantsev has also bolstered this hypothesis with the fact that the man was wearing homemade sealskin boots, the soles of which still had the hair on. Such soles are notoriously slippery and may well have contributed to his death.

For lack of a coffin the dead man's remains were placed in a wooden box and buried at the top of the slope; rocks and earth were piled on top of it and a driftwood cross erected over it. Two years later the crew of the Norwegian ship Veslekari erected a more imposing larch cross; an inscription identifying the dead man was carved in a board attached to the cross (Bolotnikov, 1949:205). In 1958 the remains were moved to the top of the cape and an imposing granite monument was erected; on a plaque is an inscription in Russian and in the Roman alphabet (Belov, 1959):

\section{TESSEM \\ Norwegian seaman, member of the expedition, MS Maud died 1920}

Before leaving Dikson Urvantsev sent a telegram briefly outlining the results of his expedition:

Novonikolayevsk. To the Committee for the Northern Sea Route; copy to Sibrevkom. Petrograd. To the Geological Committee; copy to the Geographical Society. Pyasina explored and surveyed to the mouth by boat. Travelled by sea to Dikson. On coast found Amundsen's mail, dispatched with Norwegians Knutsen and Tessem who died en route in 1920. Also found their belongings and journals. Urvantsev.

(Urvantsev, 1974:240).

On 2 September, still aboard their fishing boat, the party headed south up the Yenisey estuary and on the 6th caught up with a river steamer that had been picking up fishermen from their summer camps on the lower Yenisey. On reaching Dudinka Urvantsev met G. D. Krasinskiy, representative of Komseveroput on the Soviet of Defence and Labour, who was soon to return to Moscow. He entrusted to him Amundsen's mail, a report on his finding it, and all the belongings of the dead Norwegian he had found near Dikson. Krasinskiy undertook to deliver all this material to Narkomindel for dispatch to Norway. Interestingly, at least one of Amundsen's telegrams, addressed to his brother Leon, remained in Krasinskiy's possession and was recently discovered among his papers in the Central State Archives in Moscow (Novikova and 
Shumilov, 1977). It simply represents a summary of the expedition's progress up until 15 August 1919 , the date on which Amundsen wrote it, and unfortunately throws no light on the fate of Knutsen and Tessem.

\section{REASSESSMENTS OF THE EVIDENCE}

No further tangible evidence of what might have happened to Knutsen and Tessem came to light until 1934. In that year a Soviet party from the weather station at Mys Chelyuskina discovered a note that the Norwegians had left prior to leaving Bukhta Mod. It indicated that they had left there on 15 October 1919 with sufficient food for two weeks, counting on being able to replenish their supplies at Mys Vil'da (Shparo and Shumilov, 1982).

Based on this information, a version of the details of the tragedy of Knutsen and Tessem's journey has become widely accepted. Having replenished their supplies at Mys Vil'da, the men continued west, still by dogteam. But thereafter, due to bad weather, loss of the dogs, illness, poor hunting, or a combination of these, their progress became drastically slowed. One man (presumably Knutsen) died at Mys Primetnyy and was cremated by Tessem to prevent animals from desecrating the body. Tessem continued alone, but was obliged to abandon the mail, scientific reports, etc. only some $100 \mathrm{~km}$ short of his goal. Finally, within sight of the lights of Dikson, he slipped, knocked himself unconscious and died of exposure. This version was not challenged until more than fifty years after the event.

In 1974 the veteran arctic historian Nikita Yakovlovich Bolotnikov had occasion to re-examine in detail not only Begichev's report, but an even more thorough report on the articles found at the campfire at Mys Primetnyy, compiled in Novonikolayevsk in January 1920 by Sergey Rybin, Vice Chairman of the Research Division of Komseveroputi (Sovetnytt, 1974a; Chubakov et al., 1974). During Karlsen and Jakobsen's sojourn in Novonikolayevsk between 7 and 11 January 1920, Rybin had interviewed the two men intensively and had made a thorough inventory of the items they had recovered from the site at Mys Primetnyy. It reads as follows:

1) six discharged brass rifle shells, produced in 1912;2) a 17.5 mm brass hunting shell, produced by $H$. Untendorfer of Nürnberg, 16 gauge, also discharged; 3) cardboard shotgun shells, 16 gauge, made by Rheinische-Westfalische Sprengstoff $A / S$, unfired; 4) a metal button with the trademark of the Paris fashion house Samaritaine and another with the trademark Kodak; 5) a French 25 centime coin, dated 1903; 6) remains of a brass pocket barometer; 7) the rusted remains of a penknife and the rusty blade of a large knife; 8) half of the metal frame of a pair of spectacles or pince-nez; 9) a large smoked-glass lens from snow goggles; 10) the head of a boathook; 11) a thin strip of metal shoeing from a sledge runner; 12) a teaspoon with the trademark Alpacha; 13) pieces of thick, checked black-andwhite cotton cloth; 14) the remains of elastic, probably from snow goggles; and 15) assorted buckles, buttons, safety pins, etc.

(Sovet-nytt, 1974a; Urvantsev, 1978; Shparo and Shumilov, 1982).
On closer scrutiny, Bolotnikov's attention was caught by several anomalous aspects of this list. First, the rifle shells were dated 1912, not 1915 as Begichev had reported. Second, there was the presence of a French button and a French coin. And third, there was that baffling boathook, scarcely an item Knutsen and Tessem would have taken on a sledge journey in early winter (Knipper, 1974; Barr, 1974a). When Bolotnikov mentally ran through a list of other expeditions to which this inventory of items might possibly have belonged, he found himself reviewing the known facts of the disappearance of Rusanov's expedition aboard the schooner Hercules (Gerkules) in 1912, and immediately things began to fall into place.

In the summer of 1912 a Russian government expedition led by Vladimir Aleksandrovich Rusanov, an experienced geologist with years of field experience in Novaya Zemlya and elsewhere, was dispatched aboard the small Norwegian sealer Hercules to investigate the coal resources of Svalbard (Samoylovich, 1913; Petrasov and Derzhavin, 1945; Barr, 1974b). Rusanov and his party fulfilled this commission with admirable efficiency. But then at the end of the field season, in late August, Rusanov informed the members of his party that without official permission or collusion, rather than returning to Russia he was now going to take the 63-tonne Hercules through the Northern' Sea Route to the Pacific. Three members of the party elected to return to Russia via Norway aboard a steamer that they encountered in Svalbard waters, but the remaining 10 members, including Rusanov's French fiancée, Juliette Jean, whom he had met during his studies at the Sorbonne, elected to accompany Rusanov on his rash venture.

Heading east, on 21 August 1912 Rusanov left a final message to be telegraphed to St. Petersburg at Matochkin Shar, the strait bisecting Novaya Zemlya. It said, in effect, that he intended to round Mys Zhelaniya, the northern tip of Novaya Zemlya, and proceed east from there.

Nothing further was heard from or about Rusanov and his companions until the summer of 1934 when a party from the hydrographic vessel Stalinets, engaged in a coastal survey of the southeastern shores of the Kara Sea, found a weatherbeaten post with the inscription "Gerkules, 1913" embedded in the ground on one of the Ostrova Mona, since renamed Ostrov Gerkules. That same year another party from Stalinets recovered an assortment of articles indisputably belonging to various members of the Gerkules expedition on one of the islands of the Shkhery Minina, some $100 \mathrm{~km}$ to the southwest, and on the far side of Mys Primetnyy. The island has since been renamed Ostrov Popov-Chukhchina after two of the expedition members whose belongings were found there.

What Bolotnikov had realized was that the aspects of the finds at Mys Primetnyy which made absolutely no sense when examined in the context of Tessem and Knutsen's trip became perfectly logical when seen in the context of the Rusanov expedition. If any further proof were needed that some members of the Rusanov expedition were responsibile for the fire at Mys Primetnyy, it is provided by Yu. V. Shokarev, a researcher at the Firearms Section of the State Historical Museum, who found that the three types of rifle and shotgun 
shells found at Mys Primetnyy are identical to those from Ostrov Popov-Chukhchina (Chubakov et al., 1974). Moreover on closer examination it was found that the button with the trademark Kodak was from the strap of a Kodak camera; just such a camera had been found on Ostrov Popov-Chukhchina (Shpara and Shumilov, 1982). Indeed it is now officially recognized in the USSR that the remains found at Mys Primetnyy derive from Rusanov's expedition. In August 1978, in the presence of officers and men from the ships Valerian Al'banov and Ardatov and of the search party sponsored by Komsomol'skaya Pravda, a plaque was unveiled on the site to the memory of Rusanov and his party (Shparo and Shumilov, 1982):

Belov has correctly pointed out that one further interpretation is possible, if not very plausible (Sovet-nytt, 1974b). It is feasible that Tessem and Knutsen stumbled on one of the campsites of the Rusanov expedition, realized its significance, and took a selection of articles from it with them as demonstrable proof of their find. Later they themselves were forced to abandon these items, possibly also with things of their own, at Mys Primetnyy. This would explain the French articles, the shells identical to those from Ostrov PopovChukhchina, and even the $24 \mathrm{~cm}$ long boathook. However, one is skeptical that on a long and difficult winter sledge trip the Norwegians would have burdened themselves with quite so much excess weight; surely a few of the smallest items would have sufficed.

Although it is no longer of direct interest to this study in view of more recent findings, Bolotnikov has cast serious doubt on whether any human remains were found in the campfire at Mys Primetnyy. It is noteworthy that the bone fragments were so small and badly charred that they would have crumbled to dust if they had been moved, and hence nobody saw the bones except Begichev, Jakobsen, Karlsen, and companions. Writing later from memory in the Norwegian newspaper Morgenbladet (18 March 1922) Jackobsen wrote: "The bones were so charred that we could not reach a definite opinion as to whether they were human bones or not. But there was one bone there which was less burned, and appeared to be a human skull bone"' (Novikova and Shumilov, 1977:163). As mentioned earlier, Jakobsen was closely questioned by Sergey Rybin in Novonikolayevsk, and Rybin was certainly not convinced. In his report he wrote:

The dimensions of the individual bones, according to Jakobsen, did not exceed a length of $10 \mathrm{~cm}$; only one thin, flat bone was palm-sized; this latter bone the finders identified as a human skull bone, and it seems to me that it was on this particular bone that their conviction that a human body had been burned here was based.... The fact of the finding of the bones was so important that in questioning them about this aspect I made a special attempt to understand on the basis of what indicators the finders had become convinced that the bones had belonged to a man; as a result I remained absolutely unconvinced. (Chubakov et al., 1974:73).

Urvantsev (1978) has posed the further question of what happened to the large bones (e.g. pelvic or leg bones), if smaller bones had managed to survive the fire. And what of the teeth, the most indestructible of any part of the human body? Urvantsev is quite convinced that no human body was burned in the campfire at Mys Primetnyy.

There is even reasonably strong laboratory proof of this. In 1973 members of an expedition sponsored by the newspaper Komsomol'skaya Pravda and led by D. I. Shparo, whose primary aim was to solve the mystery of the fate of Rusanov's expedition, located the site of the campfire at Mys Primetnyy, or rather the site where Begichev and the Norwegians had buried the remains (Urvantsev, 1978). Traces of charcoal and ashes were found protruding through the gravel; beneath this surface layer they found bone remains which were carefully removed. Analysis in Moscow revealed them to be reindeer bones.

It would appear at first glance that much of the confusion concerning the bones, the dates on the shells, and similar matters could be eliminated by consulting Jakobsen's own diaries and the photographs he took at the site, or indeed by examining the articles themselves, which Rybin saw at Novonikolayevsk and which Jakobsen still had in his possession when he left there bound for Moscow and home. Unfortunately all of this material was allegedly confiscated by Russian customs officials as Jakobsen was leaving the country at Narva in late January 1922 (Chubakov et al., 1974). If this incident indeed occurred, it is extremely regrettable, but as Bolotnikov has rightly pointed out, one must remember that, especially so soon after the Interventions, all things foreign were extremely suspect in Russia, and that hence the confiscation is at least understandable. The action was presumably taken by some minor official who did not realize the significance of the articles he was confiscating (Sovet-nytt, 1974b). Shparo and Shumilov (1982) discount this story, however, and in 1973 set in motion a search in Norway for the missing documents and materials, through the auspices of the Norsk Polarinstitutt. While thus far the search has proved fruitless, Shparo and Shumilov are still convinced that the materials and documents may surface in Norway, probably among Amundsen's papers. They suspect that the missing items did indeed reach Amundsen but that he did not publicize the fact because he realized that they had no connection with Knutsen and Tessem. In support of this view they point out that as early as 1927 he wrote of the two missing men: "One was found dead close to Dickson Island. The other was never heard of. "(Amundsen, 1927:93). This indeed strongly suggests that he discounted any connection between the finds at Mys Primetnyy and the fate of Knutsen and Tessem.

It is significant that in a telegram sent to the Norwegian government by Jakobsen from Moscow on 21 January 1922, he reported the date of the rifle shells to be 1912 (Jakobsen, 1922). However, in a telegram from Moscow dated 4 January 1922 (i.e. almost two weeks before Jakobsen and Karlsen reached that city), the Norwegian official representative $F$. Jakhelln, reporting to Christiania, mentioned that the shells found were dated 1914 (Jakhelln, 1922). This discrepancy could easily be the result of a mistake by a telegraphist between Novonikolayevsk and Moscow. 
Immediately after his return to Norway Jakobsen published two accounts from memory and in both he mentions the dates of the shells; unfortunately his remarks are in part contradictory. In an interview published in Aftenposten on 17 February 1922 he menioned only rifle shells dated 1912 along with shotgun shells. But in a later report (in Morgenbladet on 18 March 1922) he mentioned several shells dated 1912 and one dated 1914. Given the thoroughness of Rybin's investigation and inventory, and the fact that he was writing with the shells in front of him, it would seem that Rybin's report is more reliable.

\section{THE SKELETON - KNUTSEN OR TESSEM?}

To add one more facet to this multidimensional mystery, recently doubt has been expressed as to whether the body found so close to Dikson was in fact that of Tessem. These doubts have been raised by Søren Richter of Norsk Polarinstitutt, in a biographical note on Tessem which he contributed to the Norsk Biografisk Leksikon (Richter, 1969). Richter focussed attention on the wedding ring with Tessem's wife's name engraved on it, and especially on the fact that it was hung on the dead man's belt rather than being on a finger. Richter found it improbable that Tessem would have carried his own wedding band in this fashion. Instead he has suggested that Tessem had died from unknown causes and that Knutsen had removed the wedding band and also the watch from the body, intending to return them to the dead man's family.

Novikova and Shumilov (1977) have similarly questioned the accepted identification of the skeleton near Dikson. They point out the fact that among the items left in the cache near the mouth of the Zeledeyeva were visiting cards of Amundsen's on which he had written letters of introduction for Tessem. Surely Tessem would not have left such crucial items behind. Knutsen, on the other hand, probably would not have known where they had been packed, and thus might have left them behind unwittingly. In similar vein Shparo and Shumilov (1982) have stressed that all the personal items found in the cache belonged to Tessem, i.e. that he was already dead or incapacitated and that Knutsen alone built the cache.

Both Urvantsev and Bolotnikov would question whether the body near Dikson could have been that of Knutsen. For one thing, if Knutsen had retrieved Tessem's watch, two watches would presumably have been found with the body; $\mathrm{H}$. Sverdrup (1933) specified that the two men had more than one watch. That there was only one ring found is inconclusive, since the hands had been gnawed off by animals, and any ring which might have been on the ring finger had disappeared. Furthermore Urvantsev has suggested that it is not entirely unusual for somebody to remove the wedding band from his own finger and carry it elsewhere on his person. Indeed he has suggested that if the man's fingers were swollen with cold or as a result of scurvy, or if the ring itself were provoking frostbite, its removal might have been essential (Urvantsev, 1973, 1974; Sovet-nytt, 1976b).

In an attempt to identify the skeleton, Shparo and Shumilov (1982) submitted photographs of it and of Knutsen and Tessem to Dr. G. V. Lebedinska, head of the Plastic Reconstruction Laboratory of the Institute of Ethnography of the Academy of Sciences, and to Dr. M. V. Kisin, head of the Biological and Special Investigations Section of the All Union Research Institute of the Ministry of Internal Affairs. In reply these scientists pointed out that the quality of the various photographs did not permit a precise comparison but they did suggest that, on the basis of the shape and size of the skull, it was very unlikely that it was Knutsen's whereas it might conceivably be Tessem's.

A more precise solution would appear to lie in one of the details of the skeleton which Urvantsev noted: namely that the back molar on the right side of the dead man's lower jaw had been filled. This surely is something that could be checked from the records of the Maud expedition, or by some relatively straightforward investigation in Norway.

\section{CONCLUSIONS}

Seen in the light of these various recent developments and hypotheses, the details of Knutsen and Tessem's journey along the Kara Sea coast assume a very different perspective. Having left Bukhta Mod on 15 October 1920 with a team of five dogs and provisions for two weeks, it took them until 10 November to cover the first lap to Mys Vil'da, a distance of some $400 \mathrm{~km}$. This relatively slow progress, and the fact that they were probably on very slim rations by the time they reached Mys Vil'da, demonstrate that they were already encountering some difficulties.

On November 15 they started west again, with food for 20 days. It can now be reasonably assumed that the sledge found at Mys Sterlegova was not theirs, and even more safely assumed that the campfire and various relics found at Mys Primetnyy are in no way connected with Tessem and Knutsen.

However, it is clear that at some stage a serious disaster struck. This was most probably at the point at which the mail was found cached. Possibly the dogs ran off after a bear or reindeer and the men were unable to find them in the dark. At any rate the two men found themselves in sufficiently dire straits that they felt obliged to abandon the mail and scientific reports, i.e. the raison d'être of the trip, although no doubt they fully intended to recover the cache as soon as they possibly could. The mail, scientific records, and equipment weighed a total of some $25 \mathrm{~kg}$ (Urvantsev, 1978), and their abandonment would certainly have lightened the load for two men accidentally deprived of their sledge and still faced with a trip of some $100 \mathrm{~km}$ on skis.

Yet some $35 \mathrm{~km}$ farther west, near the mouth of the Uboynaya, even the skis were discarded. One can only conjecture that conditions must have been totally impossible for skiing. Possibly strong winds or a freak thaw had left vast areas of tundra snow-free. Only something as drastic as that would have made Norwegians abandon their skis.

On the very last lap one of the two men disappeared. Urvantsev (1978) has suggested that this might have occurred at Bukhta Polyniya, only $12 \mathrm{~km}$ east of Dikson. This bay is notorious for having patches of very thin ice, abraded by cur- 
rents from below, which become treacherously masked by snow. The residents of Dikson treat the ice of this bay with a great deal of respect.

The Norwegians, unsuspecting, may have cut straight across the bay and Knutsen may well have fallen in and drowned. Tessem, who may also have fallen in and been thoroughly soaked as well as badly shaken, would have headed across the tundra and would have emerged at the cape directly across Proliv Proven from the Dikson weather station. Whether he then slipped and was knocked out, as Urvantsev has suggested, or sat down to wait for daylight to cross this last obstacle, and fell asleep and froze to death, as Troitskiy has suggested (Sovet-nytt, 1974b), remains yet another area of conjecture. What is definite, however, is that the two Norwegians, and especially the lone survivor, had made a truly remarkable sledge trip, and probably the most tragic aspect is that the latter had come so close to reaching his goal.

From the articles appearing in Sovet-nytt, and particularly from correspondence in the Norsk Polarinstitutt archives from relatives and friends of Knutsen and Tessem and from interested Norwegians, it is clear that the complex mystery of the deaths of Tessem and Knutsen is still of very great interest in Norway. Repeatedly, however, one is struck by the fact that the answers to many aspects of the mystery must lie in Norway in documents pertaining to the Maud expedition, either in archival collections or in private hands. The matter of which of the two men, Knutsen or Tessem, had had a right lower molar filled, so vital to identification of the skeleton which was found, is a good example of this. Similarly it seems probable that the details of construction of the sledge that Tessem built must be recorded somewhere. This article has been written with three main purposes in mind: to bring the details of this complex tragedy to the notice of the English-speaking world; to emphasize the significant effort made by the Soviet government and by individuals in Siberia at the time to find the missing men, an aspect perhaps not fully appreciated in Norway; and to stimulate Norwegian researchers to an even more intensive search for clues to the deaths of Tessem and Knutsen.

\section{ACKNOWLEDGEMENTS}

I should like to thank Mrs. Karla Jessen Williamson, Dr. Arnie Paus-Jensen, Dr. Vincent Malmstrom and Dr. Peter Schledermann for their generous assistance in translating various of the Norwegian materials for me. I am also indebted to Mr. Knut Heggelund of the Norsk Polarinstitutt for sending me various documents pertaining to the disappearance of Knutsen and Tessem, and to the editors of Priroda for providing the photographs reproduced as Figures 4 and 5 . And finally my thanks are also due to Mr. Hal Espy for drafting the maps.

\section{REFERENCES}

AMUNDSEN, R. 1908. The North West Passage; being the record of a voyage of exploration of the ship "Gjöa" 1903-1907. Vol. 2. New York: E. P. Dutton and Co. 397 p.

1921. Nordostpassagen. Maudfaerden langs Asiens kyst 1918-1920. Kristiania: Gyldendalske boghandel. $467 \mathrm{p}$. $282 \mathrm{p}$.

1927. My life as an explorer. London: William Heinemann Ltd.

BARR, W. 1974a. Right place: wrong skeleton! The Musk-Ox 14:59-60. 1974b. Rusanov, Gerkules and the Northern Sea Route. Canadian Slavonic Papers 16(4):569-611.

1981a. Baron Eduard von Toll's last expedition: the Russian Polar Expedition 1900-1903. Arctic 34(3):201-224.

1981b. Aleksandr Vasil'yevich Kolchak: arctic scientist and explorer. Polar Record 20(129):507-524.

BELOV, M. I. 1956. Arkticheskoye moreplavaniye s drevneyshikh vremen do serediny XIX veka. Istoriya otkrytiya $i$ osvoyeniya Severnogo Morskogo Puti, tom I [Arctic seafaring from the earliest times to the midnineteenth century. History of the discovery and exploitation of the Northern Sea Route, Vol. I]. Moscow: Izdatel'stvo "Morskoy Transport". $592 \mathrm{p}$.

1959. Sovetskoye arkticheskoye moreplavaniye 1917-1932 gg. Istoriya otkrytiya i osvoyeniya Severnogo Morskogo Puti, tom III [Soviet arctic navigation, 1917-1932. History of the discovery and exploitation of the Northern Sea Route, Vol. III]. Leningrad: Izdatel'stvo "Morskoy Transport". $510 \mathrm{p}$.

BOLOTNIKOV, N. 1949. Nikifor Begichev. Moscow: Izdatel'stvo Glavsevmorputi. $230 \mathrm{p}$.

CHUBAKOV, N. I., SHPARO, D. A. and SHUMILOV, A. V. 1974. Where should one search for traces of the Rusanov expedition? Part 2. Priroda 9:69-75.

FIALA, A. 1907. Fighting the polar ice. London: Hodder and Stoughton. $296 \mathrm{p}$.

JAKHELLN, F. 1922. Telegram from Moscow to Norwegian Foreign Ministry, 4 January 1922. (Original held by Norsk Polarinstitutt.)

JAKOBSEN, L. 1922. Telegram from Moscow to Norwegian Government, 21 January 1922. (Original held by Norsk Polarinstitutt.)

KNIPPER, V. 1974. Where are you, Gerkules? Vodnyy Transport, 7 February 1974:3

KOLOMEYTSEV, N. N. 1902. The Russian Polar Expedition under the leadership of Baron Toll. Izvestiya Imperatorskago Russkago Geograficheskago Obshchestva 38(3):342-369.

NOVIKOVA, A. A. and SHUMILOV, A. V. 1977. An unknown telegram from Amundsen and the fate of his companions. Letopis' Severa 8: $158-168$

PETRASOV, S. P. and DERZHAVIN, M. S. 1945. The life and achievements of V. A. Rusanov; a biographical sketch. In: Tsvetkova, A. N. (ed.). Vladimir Aleksandrovich Rusanov: stat'i, lektsii, pis'ma [Vladimir Aleksandrovich Rusanov: articles, lectures and letters]. MoscowLeningrad: Izdatel'stvo Glavsevmorputi. 5-59.

RICHTER, S. 1969. Peter Lorents Tessem. In: Jansen, J., Anker, $\emptyset$. and Bøe, G. (eds.). Norsk Biografisk Leksikon, Vol. 16. Oslo: Forlagt av H. Aschehoug and Co. (W. Nygaard). 128-131.

SAMOYLOVICH, R. 1913. The island of Spitzbergen and the first Russian scientific-commercial expedition. Izvestiya Arkhangel'skogo Obshchestva Izucheniya Russkago Severa 4:169-174; 5:217-233; 6:268-283.

SHPARO, D. I. and SHUMILOV, A. V. 1975. Along Begichev's route; in Rusanov's tracks. Priroda 19:85-89.

1982. Tri zagadki Arktiki [Three arctic mysteries]. Moscow: "Mysl" ". $142 \mathrm{p}$.

SOVET-NYTT. 1974a. Hvorfor og hvor omkom Tessem og Knutsen? Ny versjon om deres skjebne. Sovet-nytt 28 (17 August 1974):4.

1974b. Hvorfor og hvor omkom Tessem og Knutsen? Sovet-nytt 29 (31 August 1974):3.

STAROKADOMSKIY, L. M. 1976. Charting the Russian Northern Sea Route. The Arctic Ocean Hydrographic Expedition, 1910-1915. Montreal and London: The Arctic Institute of North America and McGill Queen's University Press. 332 p.

SVERDRUP, H. U. 1933. General report of the expedition. In: Sverdrup, H. U. (ed.). The Norwegian North Polar Expedition with the "Maud", 1918-1925. Scientific results, Vol. IA, Special Reports. Bergen: A. S. John Griegs Boktrykeri, 1-22.

SVERDRUP, O. 1928. Under Russisk flag. Oslo: Forlagt av H. Aschehoug and Co. 162 p. 
THE TIMES. 1920. Explorers missing: message from Captain Amundsen. 1 April 1920:15.

TOLL, E. (ed.). 1909. Die Russische Polarfahrt der "Sarja" 1900-1902 aus den hinterlassenen Tagebüchern von Baron Eduard von Toll. Berlin: Georg Reimer. 635 p.

TROITSKIY, V. A. 1977. N. A. Begichev's geographical discoveries in Taymyr. Letopis' Severa 8:133-145.

URVANTSEV, N. N. 1973. Letter to Peter Hagevold, Norsk Polarinstitutt, dated Moscow, 28 September 1973. (Original held by Norsk Polarinstitutt.)

1974. How we found Amundsen's mail: from an explorer's journal. In: Bolotnikov, N. Ya. (ed.). Polyarnyy Krug: sbornik [The Arctic Circle: a collection]. Moscow: "Mysl" ". 232-242.

1978. Taymyr - kray moy severnyy [Taymyr - my northern land]. Moscow: "Mysl" ". 245 p.

WISTING, O. 1930. 16 ar med Roald Amundsen: fra pol til pol. Oslo: Gyldendal Norsk Forlag. 206 p. 